\title{
МОНГОЛ ОРНЫ ГОВИЙН НУТАГТ ШОРООН ШУУРГА ШУУРАХ УЕИЙН РМ10 ТООСНЫ АГУУЛАМЖ
}

\author{
Д.Ж гдээр $^{1}$, Д.Батдоржж${ }^{1}$, I. Matsui ${ }^{2}$, Dr.N.Sugimoto ${ }^{2}$, Dr. M.Nishikawa ${ }^{2}$

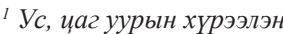 \\ ${ }^{2}$ National Institute for Environmental Studies, Japan
}

\section{Оршил}

Агаар дахь нарийн ширхэгт тоос, тоосонцорын эх үүсвэр нь байгалийн гаралтай байхаас гадна хүний үйл ажиллагаатай холбоотой. Агаар дахь тоос шороон шуурга, галт уулын дэлбэрэлт, ой хээрийн түймэр, амьд ургамал, далайн цалгидасаас үүдэлтэй байвал байгалийн гаралтай тоос гэж үздэг. Харин шатахуун, нүүрсний шаталт, нүүрс шатаадаг эрчим хүч, дулаан, цахилгааны үйлдвэрүүд, уурхай, барилга байгууламж, газар шорооны бусад үйл ажиллагаа, хөрсний элэгдэл, замын тоос, автотээврийн хэрэгслээс гарах утаа зэрэг олон төрлийн үйлдвэрлэлийн явцаас агаарт дэгдсэн тоос, тортог нь хүний үйл ажиллагаатай холбоотой юм.

Өнөө үед агаар дахь тоос, түүнийг дагалдах химийн элемент, нэгдлүүдийг хэмжих нарийн технологи бүхий багажууд үйлдвэрлэгдэн ашиглагдаж байна. Агаар дахь тоос нь агаар бохирдуулагчдын нэгд орно. Шороон шуурга, тоос нь агаарын урсгалаар алсад зөөгдөж байдаг бөгөөд хүний эрүүл мэнд, электроникийн үйлдвэрлэл, барилга болон бүх төрлийн тээврийн хэрэгслийн үйл ажиллагаа, манай орны мал аж ахуй зэрэг олон салбарт сөрөг нөлөө үзүүлдэг. Иймд зүүн-хойд Азийн орнууд бүс нутгийн хэмжээнд шороон шуургыг бүх талаас нь хамтран судлаж байна.

Энэхүү судалгаагаар Монгол оронд 2007-2009 онд шинээр байгуулагдсан тоосны мониторингийн станцууд дээр дэвшилтэт техник, төхөөрөмж, технологиор хэмжсэн тоосны агууламжийн мэдээг боловсруулах, Монгол орны шороон шуурга, тоосны агууламжийн оронзай, цаг хугацааны тархалтын талаар судалгааны шинэ үр дүн гаргах зорилт тавьсан болно.

\section{Ашигласан мэдээ хэмжилтийн технологи}

Монгол орны говийн нутагт орших Сайншанд, Замын-Үүдэд 2007 оны 9 дүгээр сараaс 2008 оны 4 дүгээр сард хэмжсэн РМ10 тоосны агууламж, салхины хурдны мэдээг судалгаанд ашиглав. Салхины хурдны минут тутмын, РМ10 тоосны цаг тутмын мэдээг цаг агаарын газар орчмын болон өндрийн зураг мэдээлэлтэй хамтад нь авч судлав.

Тоосны хэмжилтийн багаж нь нефлометрийн аргаар хэмжилт хийх бөгөөд хэмжилтийн энэ арга нь агаар дахь тоосны эгэл хэсгээс ойх гэрлийн ойлтод үндэслэгдсэн байдаг.

Тоосны босоо чиглэлийн тархалтыг хэмждэг лидарын хэмжилтээс туйлшралыг арилгах харьцаа, буцан-ойх ойлтын коэффициентийн өдөр тутмын мэдээг ашиглав. Лидар нь туйлшралыг тооцох чадамжтай бөгөөд хэмжилтийн долгионы урт нь $532 \mathrm{~nm}$ and 1064 nm болно. [Sugimoto et.al., 2005; Ikuko Mori et.al. 2002]. 
Судалгааны үр дүн

Монголын говийн нутгийн РМ10 тоосны агууламж

ЭнэхүҮ судалгаагаар Монголын говийн нутгийн РМ10 тоосны агууламжид жилийн болон хоногийн явц илэрч байна (Зураг 1, Зураг 2).

Замын-Үүдийн РМ10 тоосны агууламжийн хоногийн явцад 2 их утга илэрч байгаа бөгөөд эхний их утга нь өглөөний 9 цагийн үед, хоёр дахь их утга нь оройн 19 цагаас эхлэж байна. Өвлийн улиралд өглөө, оройд РМ10 тоосны агууламж ихсэж байгаа нь ахуйн болон халаалтын зориулалтаар нүүрс шатааж байгаатай холбоотой.

Жилийн явцын хувьд Монголын говийн нутагт РМ10 тоосны агууламж өвөл, хаварт ихсэж байна. Энэ нь хаврын улиралд агаар мандлын фронт, циклоны үйлчлэлээр агаарт тоос, шороо дэгдэж, шороон шуурганы давтагдал ихэсдэгтэй холбоотой юм (Зураг 1, Зураг 2). Хаврын улиралд гурав, дөрөвдүгээр сард РМ10 тоосны агууламжийн хоног, жилийн явц эвдэрч, хаварт ихсэхийн зэрэгцээ үдээс хойш 12-16 цагт хамгийн их утга нь ажиглагдаж байна.

РM10 тоосны агууламжийн сарын дундаж утга Замын-Үүдэд 2007 оны есөөс аравдугаар сард 13 мкг/м³ 2007 оны 11 дүгээр сараас 2008 оны дөрөвдүгээр сард 30-41

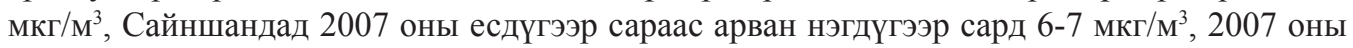
аравдугаар сараас 2008 оны гуравдугаар сард 11-15 мкг/м³ байв /Зураг 3/.

PM10 тоосны агууламжийн хоногийн дундаж утга шороон шуургатай үед ихэсч байна. Тухайлбал, 2008 оны 3 дугаар сарын 14, 4 дүгээр сарын 20-ны өдрүүдийн шороон шуурганы үед Замын-Үүдэд РМ10 тоосны агууламжийн хоногийн дундаж утга харгалзан

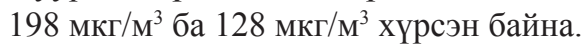

Өвлийн улиралд антициклонлог цаг агаартай өөрөөр хэлбэл салхигүй тогтуун үед агаарын бохирдлын улмаас РМ10 тоосны агууламжийн хоногийн дундаж утга ихэсч байна. Жишээ нь, 2007 оны 12 дугаар сарын 25-нд Замын-Үүдэд РМ10 тоосны агууламжийн хоногийн дундаж утга 110 мкг/м³ болсон байна.

РМ10 тоосны агууламжийн үнэмлэхүй их утга хаврын улиралд шороон шуурга шуурах үед ажиглагдаж байна /Зураг 4/.

Замын-Үүд

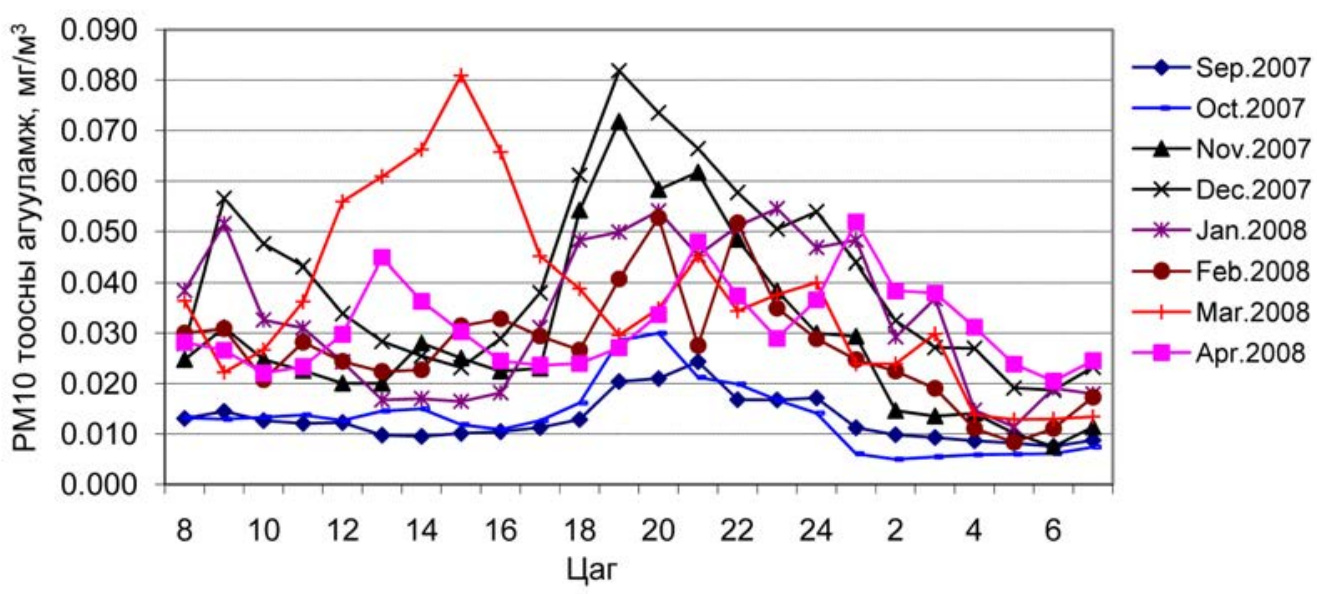

Зураг 1. Замын-ҮҮдийн РМ10 тоосны агууламжийн жилийн болон хоногийн яви

$$
-67-
$$




\section{Сайншанд}

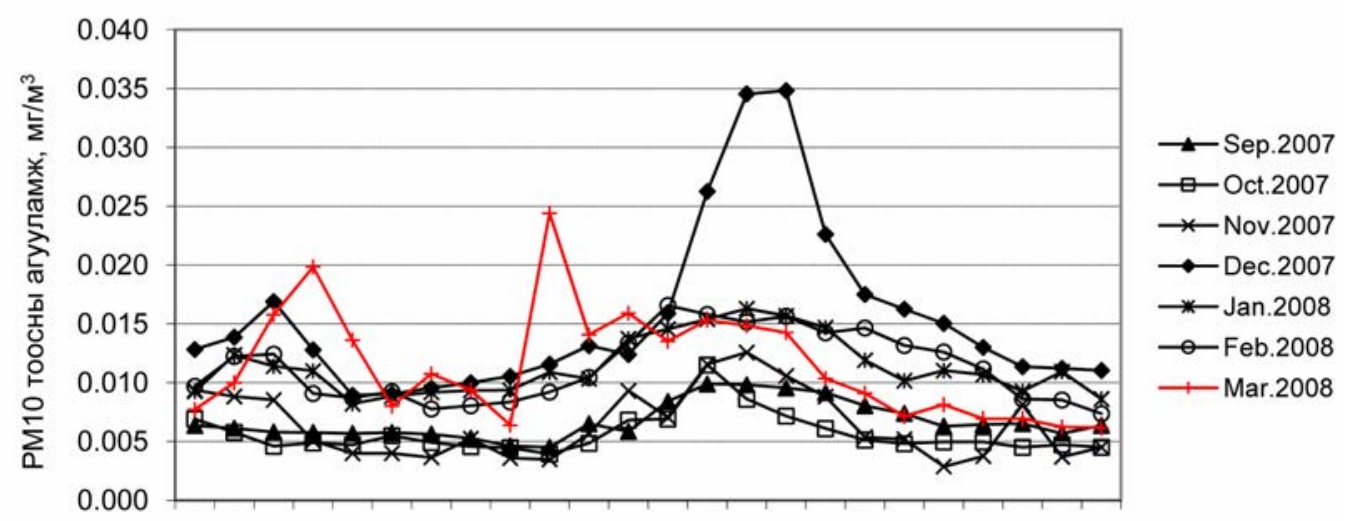

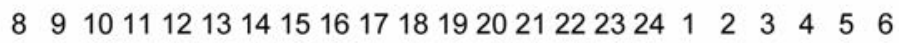
Цаa

Зураг 2. Сайншандын РМ10 тоосны агууламжийн жилийн болон хоногийн яви

PM10 тоосны сарын дундаж агууламж, мг/M³

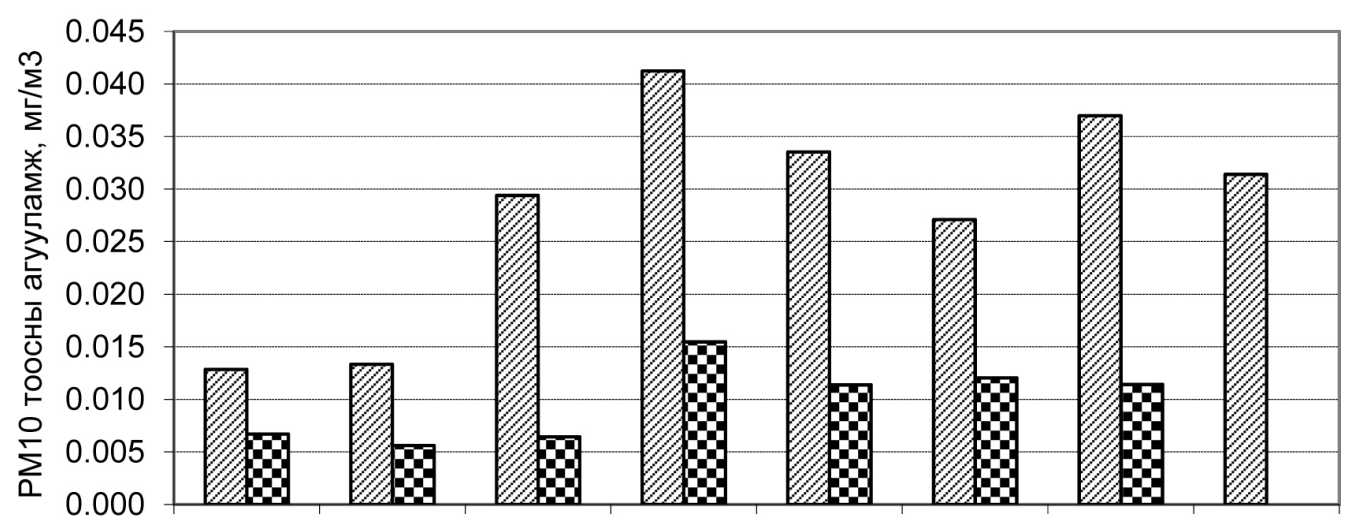

Sep.2007 Oct.2007 Nov.2007 Dec.2007 Jan.2008 Feb.2008 Mar.2008 Apr.2008 $\mathrm{OH}$, cap

aZamyn-Uud $\mathbf{\square}$ Sainshand

Зураг 3. Сайншанд, Замын-ҮҮдийн РМ10 тоосны сарын дундаж агууламж 


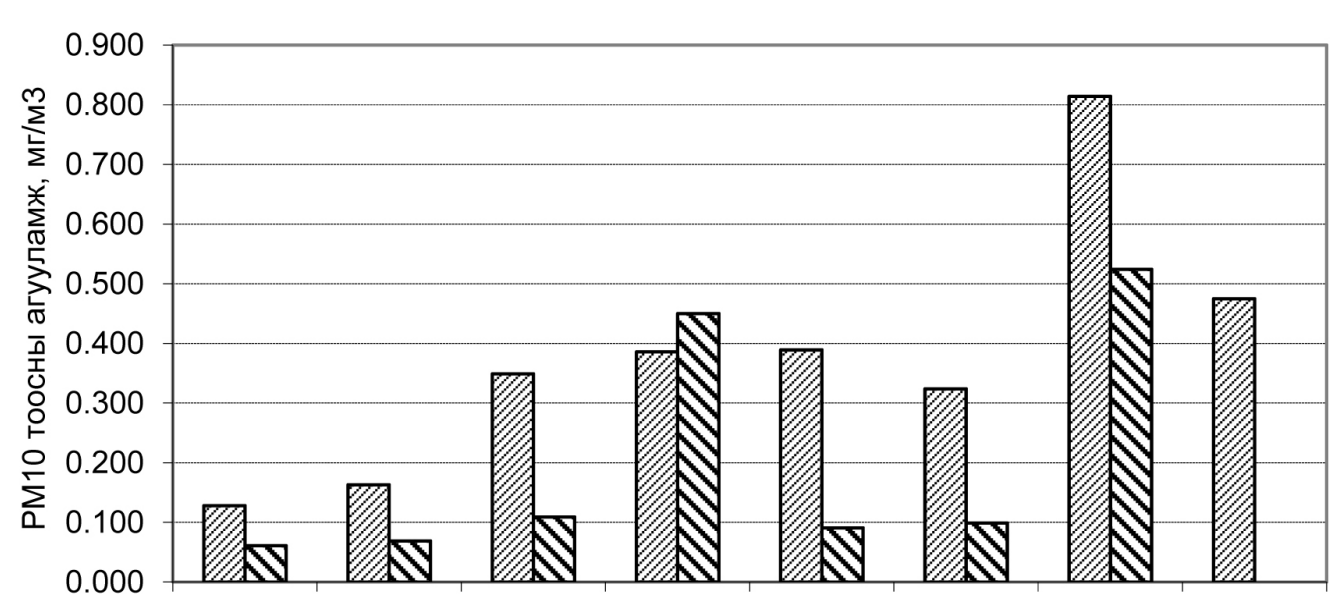

Sep.2007 Oct.2007 Nov.2007 Dec.2007 Jan.2008 Feb.2008 Mar.2008 Apr.2008

$\mathrm{OH}$, cap

\section{DZamyn-Uud \$Sainshand}

Зураг 4. Сайншанд, Замын-ҮҮдийн РМ10 тоосны агууламжийн үнэмлэхүй их утга

\section{Тухайлсан судалгаа}

\section{8 оны 3 дугаар сарын 13-17}

2008 оны 3 дугаар сарын 14-ний 02 цагт Монгол орны Хангай нурууны зүүн хойд салхин доод талд нэгэн циклон үүсч зүүн урагш говийн нутгийн зүүн хэсгийг дайран шилжиж энэ циклон, түүний фронтын нөлөөгөөр салхины хурд 12-24 м/с хүрч, хүчтэй шороон шуурга шуурсан байна. 2008 оны 3 дугаар сарын 14-ний 02 цагаас 11 цагийн хоорнд хүйтэн фронт Сайншанд, Замын-Үүдийг дайран шилжих үед салхины хурд 8-23 м/с хүрч, эдгээр станцын орчинд шороон шуурга 8-11 цаг үргэлжилснийг тоосны хэмжилтийн багажийн бичлэгээр тогтоосон юм /Зураг 5а, 5б, 7а, 7б/.

Замын-Үүдэд РМ10 тоосны агууламж 2008 оны 3 дугаар сарын 14-ний 02 цагаас эхлэн өсч шороогоор шуурах хугацаанд 306 мкг/м ${ }^{3}$-аaс 814 мкг $/ \mathrm{M}^{3}$ хүрч өссөн байна / Зураг 5а, 5б/. Энэ шороон шуурганы үед Замын-Үүдэд салхины хурд 20 м/с хүрч, 7 цагийн турш тоосны агууламж өндөр байсан байна. Харин Сайншандад 2008 оны 3 дугаар сарын 14-ний шөнийн 01 цагаас өглөөний 9 цагт салхины хурд 8 м/с-ээс 23 м/с -ийн хооронд хэлбэлзэж, РМ10 тоосны агууламж ихсэхгүй байснаа салхи намжиж 7 м/с орчим болох үеэс РМ10 тоосны агууламж өглөөний 10 цагаас өссөн нь хүйтэн фронтын ард тоосны агууламж ихсэх тохиолдол байдгийг харуулж байна /Зураг 7a, 7б/.

Энэ судалгааны үед хэмжилтийн мэдээнд дүн шинжилгээ хийх явцад Монголын говийн нутагт салхины хурд 15 м/с хүрэхэд РМ10 тоосны агууламж ихсэж байгааг багажийн хэмжилтийн мэдээгээр тодрууллаа.

2008 оны 3 дугаар сарын 10-наас 15-ны өдрүүдийн Лидарын ажиглалтын мэдээгээр шороон шуурга шуурах үеийн тоосны босоо чиглэлийн тархалт 2 км хүртэл өндөрт их нягтралтай илэрсэн байна. Хамгийн их нягт тоос 2008 оны 3 дугаар сарын 14-нд ажиглагдсан байна /Зураг $6,8 /$. 


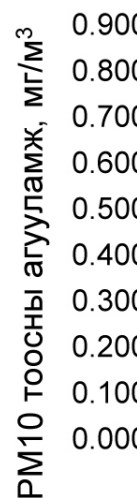

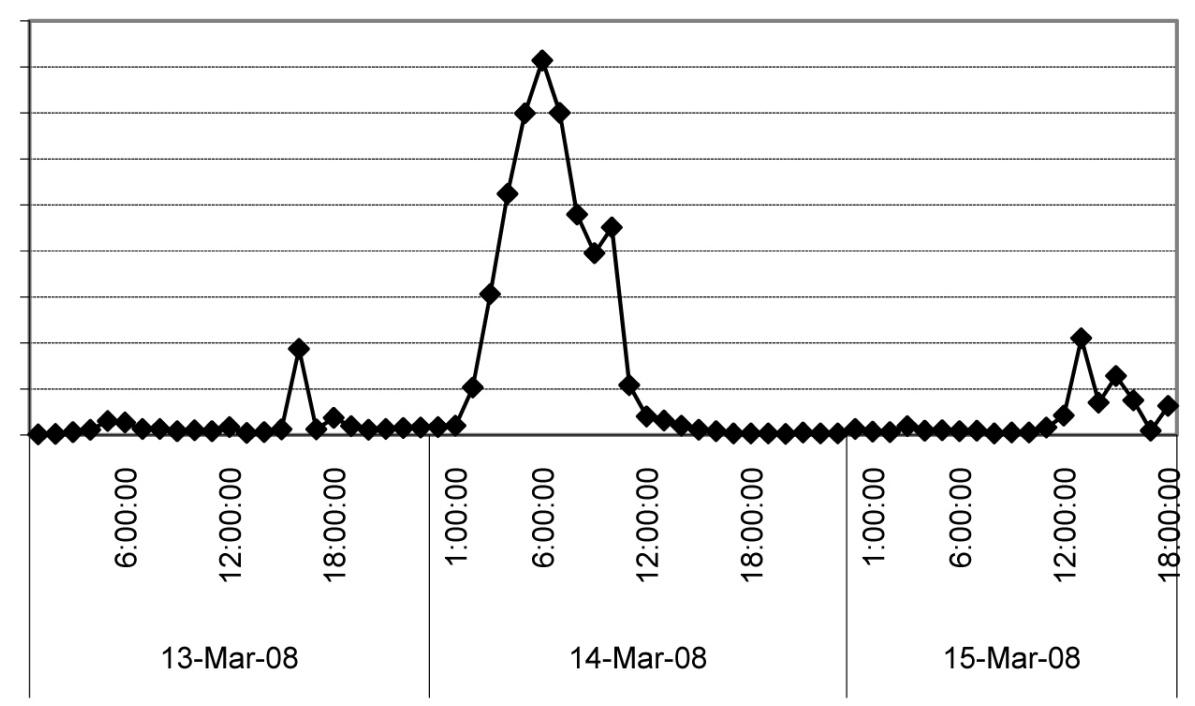

Он, сар, өдөр, цаг

Зураг 5а. 2008 оны 3 дугаар сарын 14-ний шороон шуурганы үед Монголын говийн нутагт /3амылнҮҮд/ ажиглагдсан РМ10 тоосны агууламж

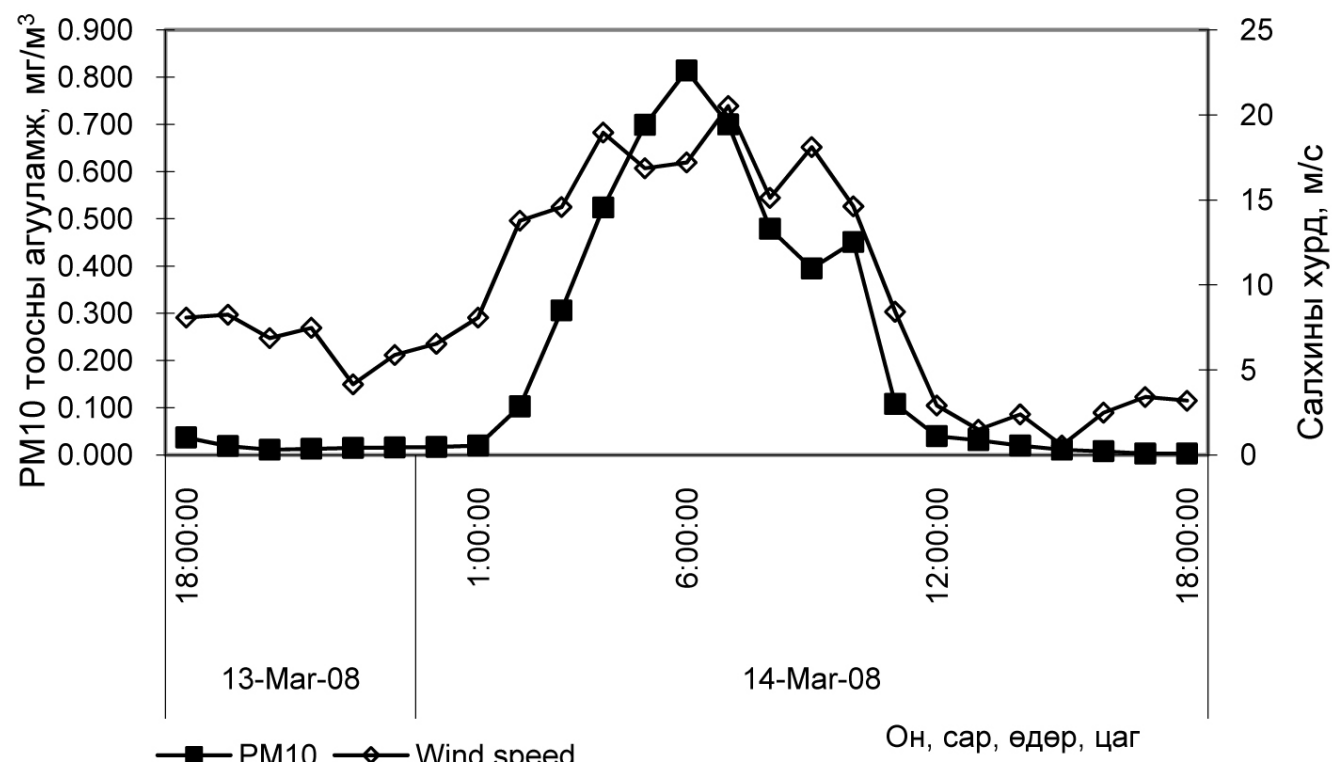

Зураг 5б. 2008 оны 3 дугаар сарын 14-нд Монгольн говийн нутагт /Замын-ҮҮд/ ажиглагдсан салхины их хурд 


\section{Lidar Observation in Zamynuud}
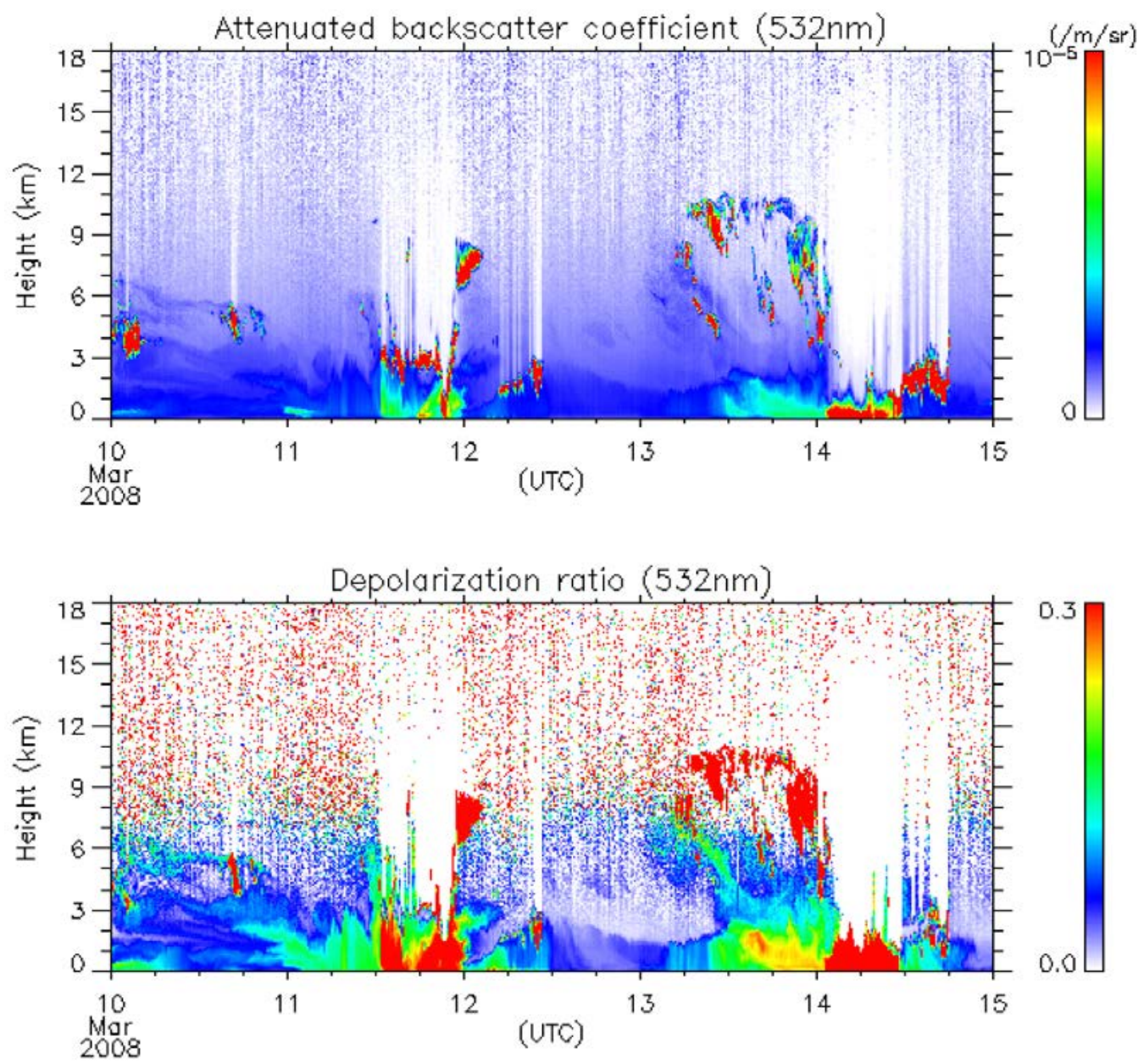

Зураг 6. 2008 оны 3 дугаар сарын 10-наас 15-ныл өдрүҮдэд Монголын говийн нутагт /Замын-ҮҮд/ ажиглагдсан шороон шуурганы үеийн лидарын хэмжслтийн мэдээ 


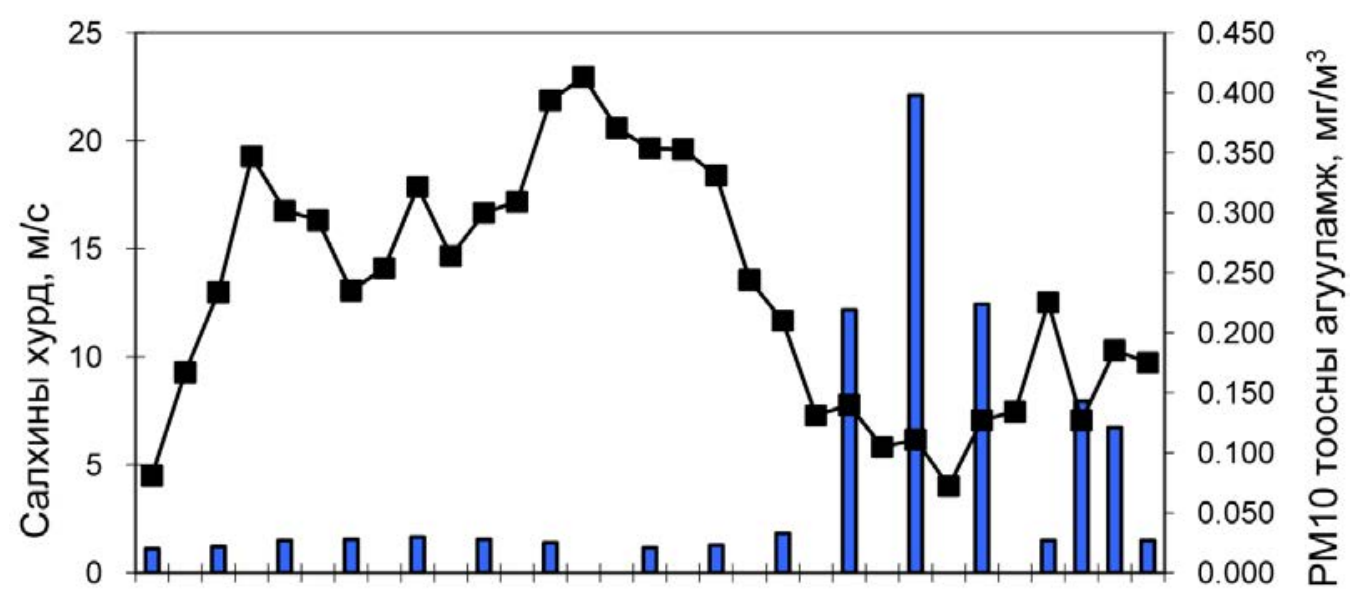

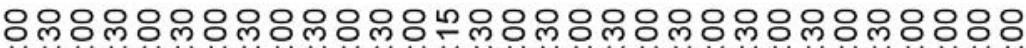

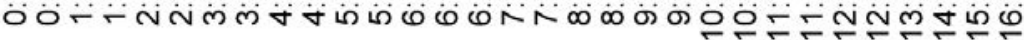

2008 оны 3-р сарын 14-ний өдөр, цаг

$\longrightarrow$ एव10 $\rightarrow$ wind

Зураг 7а. 2008 оны 3 дугаар сарын 14-ний өдөр Монгольн говийн нутагт /Сайншанд/ ажиглагдсан салхины хурд

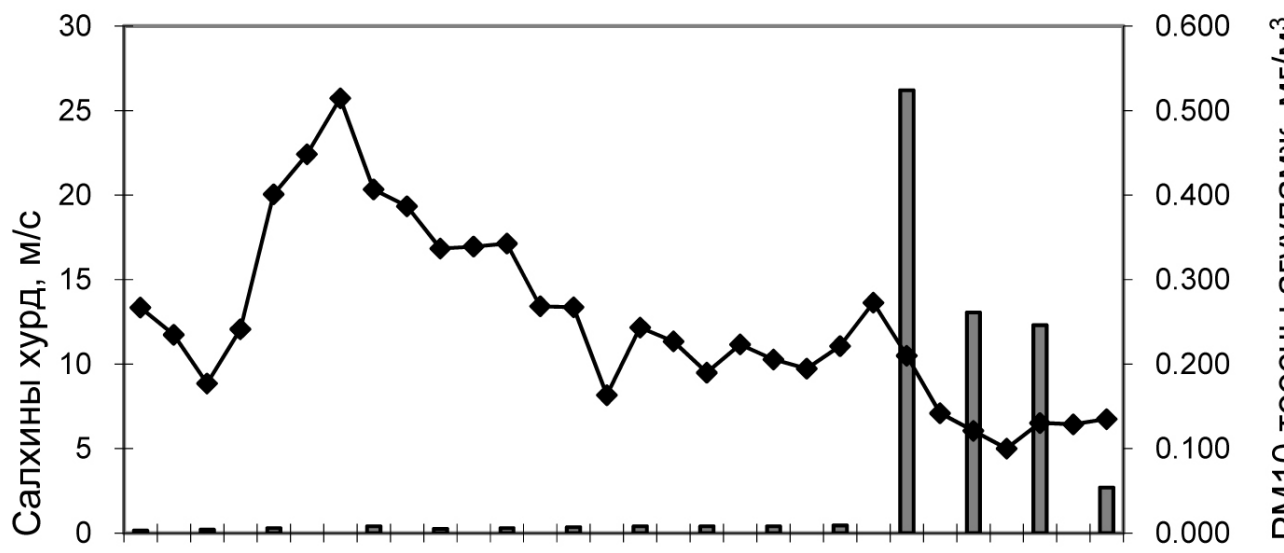

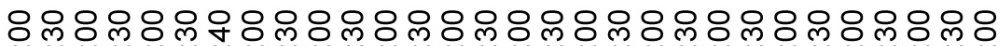

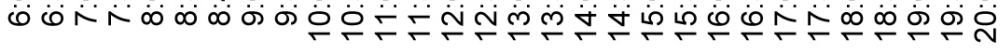

2008 оны 3-р сарын 17-ны өдөр, цаг

凹PM10 $\longrightarrow$ wind

Зураг 7б. 2008 оны 3 дугаар сарын 17-ны өдөр Монгольн говийн нутагт /Сайншанд/ ажиглагдсан РМ10 тооснь агууламж 


\section{Lidar Observation in Sainshand}
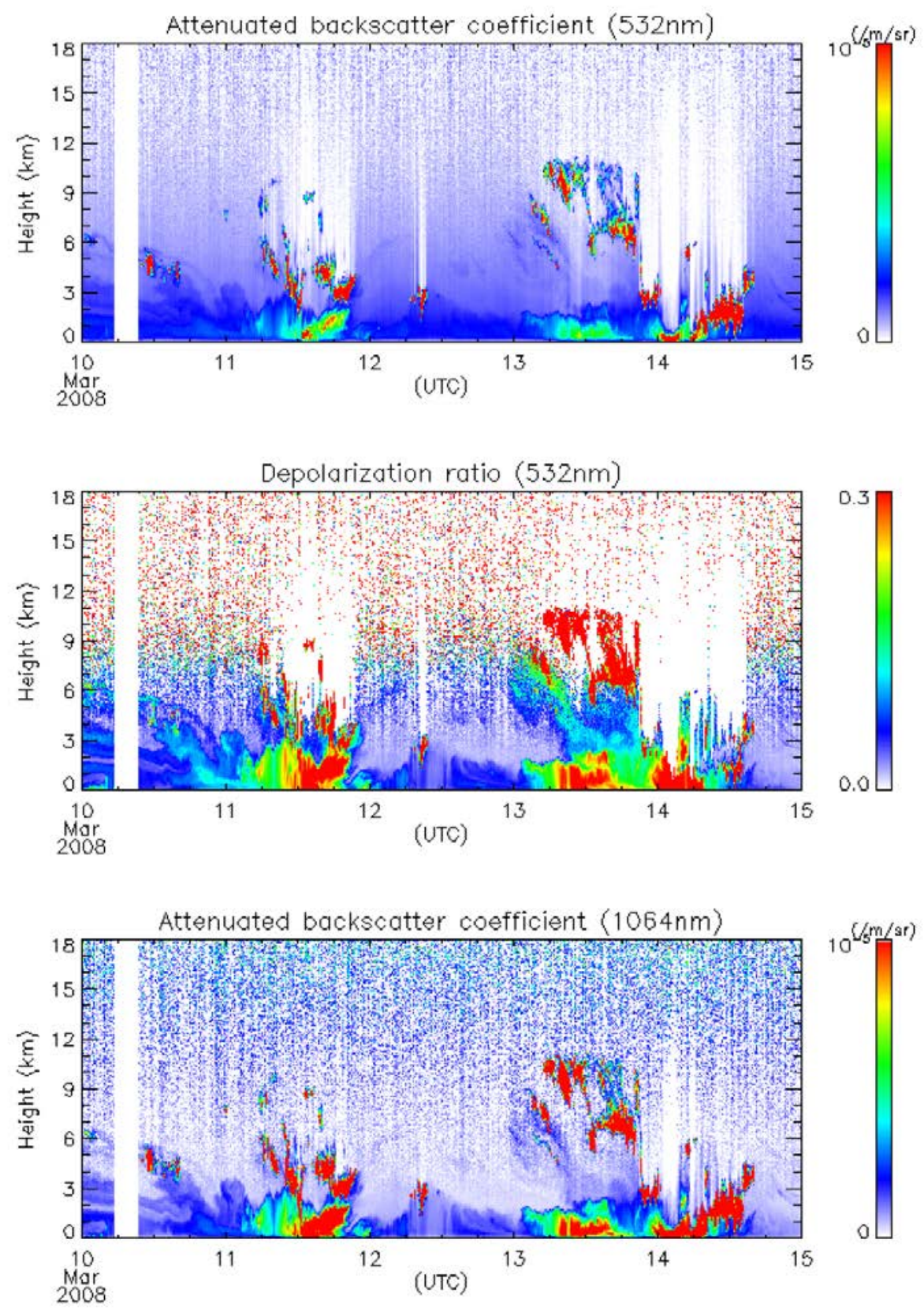

NAMHEM/MNE

Created:Sat Mar 15 07:57:05 2008(MST)

Зураг 8. 2008 оны 3 дугаар сарын 10-наас 15-ны өдрүҮдэд Монголын говийн нутагт /Сайншандад/ ажиглагдсан шороон шуурганы үеийн Лидарын хэмжилт 


\section{Дүгнэлт}

1. РМ10 тоосны агууламжийн сарын дундаж утга хүйтний сарууд (11 дүгээр сараас 2 дугаар сар) болон хаврын саруудад хамгийн их байна. (3 болон 4 дүгээр сар).

2. РМ10 тоосны агууламж циклон, хүйтэн фронт дайран өнгөрөх үед, түүнчлэн өвлийн халаалт дулааны ажиллагаатай холбоотой өсч байна.

3. 2008 оны хавар шороон шуурга шуурах үед Замын-Үүдэд РМ10 тоосны үнэмлэхүй их утга 814 мкг $/ \mathrm{M}^{3}$ хүрэв.

4. Монгол орны говийн нутагт салхины хурд 15 м/с -ээс их болох үед агаарт нарийн ширхэгтэй шороо, тоос /PM10/ их босдог байна.

5. РМ10 тоосны агууламж хүйтэн фронтын бүсэд, мөн түүний ар хэсэгт өсч байна.

6. Лидарын мэдээгээр Монголын говийн нутагт үүссэн шороон шуурганы үед агаарт дэгдсэн тоос босоо чиглэлд 4 км хүрч тархаж байна.

Талархал: Монгол оронд тоосны хэмжилтийн багаж тоног төхөөрөмж суурилуулсан Япон улсын засгийн газар, ЖАЙКА байгууллагад баярлан талархаж буйгаа илэрхийлье.

\section{Ном зүй}

D.Jugder, Ichiro Matsui, Masataka Nishikawa and Nobuo Sugimoto, 2007: TSP and PM10 concentrations in Ulaanbaatar in spring 2007, Papers in Meteorology and Hydrology, No.29, Ulaanbaatar.

Ikuko Mori, Masataka Nishikawa, Hao Quan and Masatoshi Morita, 2002: Estimation of concentration and chemical composition of kosa aerosols at their origin, Journal of Atmospheric Environment, 36 (2002), p. 4569-4575.

Sugimoto, N., A. Shimizu, I. Matsui, U. Itsushi, K. Arao, Y. Chen, S. Zhao, J. Zhou, and C-H. Lee, Study of Dust Transport Using a Network of Continuously Operated Polarization Lidars, Water, Air, and Soil Pollution: Focus 5, 145-157, 2005. 